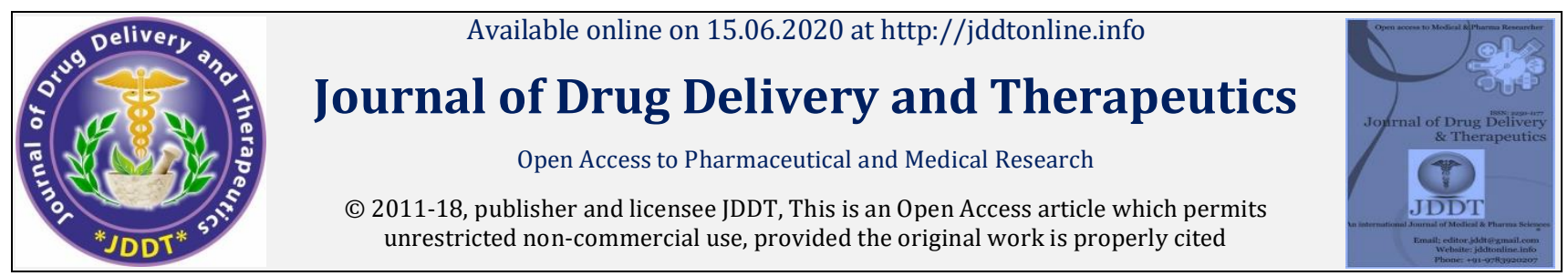

Open $\odot$ Access

Research Article

\title{
Comparative Biological Activity Profile of Nava (Freshly Collected) and Purana (Old) Dhanyaka (Coriandrum sativum Linn.) through Gas Chromatography and In-Vitro Anti-Microbial Study
}

\author{
Chaithra $^{1}$, Mallya Suma V ${ }^{2 *}$, Prabhu Suchitra ${ }^{3}$ \\ ${ }^{1}$ PG Scholar, Sri Dharmasthala Manjunatheshwara College of Ayurveda, Kuthpady, Udupi, Karnataka 574 118, India \\ 2 Associate Professor, Sri Dharmasthala Manjunatheshwara College of Ayurveda, Kuthpady, Udupi, Karnataka 574 118, India \\ ${ }^{3}$ Research Officer, Sri Dharmasthala Manjunatheshwara College of Ayurveda, Kuthpady, Udupi, Karnataka 574 118, India
}

\begin{abstract}
Introduction: Dhanyaka(Coriandrum sativum Linn.) belonging to family Apiaceae is one such common aromatic edible herb, the fruits of which are used as carminative, antimicrobial and cooling. Classical texts of Ayurveda advocate these fruits to be used in old condition. With this background, a study was done to compare biological activity profile of Nava and Purana Dhanyaka(Coriandrum sativum Linn.) through, Gas chromatography and in-vitro anti-microbial activity. Materials and methods: Fresh fruits of Dhanyaka(Coriandrum sativum Linn.) were collected from Rona, Gadag district and authenticated. The fresh fruits named as S1 with which essential oil extracted using clevengers apparatus. Few fruits were kept in an air tight container and stored for one year, and at the end of a year named as sample( $\left.\mathbf{S}_{2}\right)$, essential oil extracted and stored. Both samples were subjected for GC and in-vitro antimicrobial activity. Results and Discussion: The Essential oil of Nava Dhanyaka $\left(\mathbf{S}_{\mathbf{1}}\right)$ included 17 identified compounds which was dominated by monoterpenes and sesquiterpene; whereas $\boldsymbol{S}_{2}$ showed 6 identified compounds in which 3 constituents isoborneol, citronellyl acetate and geraniol were new findings. In-vitro anti-microbial study of essential oil extract showed that Purana Dhanyaka $\left(\mathrm{S}_{2}\right)$ had better efficacy with respect to the standard against the strain Escherichia coli and Candida albicans; whereas that of Nava Dhanyaka $\left(\mathrm{S}_{1}\right)$ against only one bacterial strain ie., Streptococcus pyogens. Conclusion: Preservation of Dhanyaka(Coriandrum sativum Linn.) showed biological changes in terms of antimicrobial activity compared to fresh sample.
\end{abstract}

Key words: Dhanyaka, Coriandrum sativum Linn., Gas chromatography, In-vitro antimicrobial study

Article Info: Received 21 March 2020; Review Completed 28 April 2020; $\quad$ Accepted 11 May 2020; Available online 15 June 2020

Cite this article as:

Chaithra, Mallya SV, Prabhu S, Comparative Biological Activity Profile of Nava (Freshly Collected) and Purana (Old) Dhanyaka (Coriandrum sativum Linn.) through Gas Chromatography and In-Vitro Anti-Microbial Study, Journal of Drug Delivery and Therapeutics. 2020; 10(3-s):12-16 http://dx.doi.org/10.22270/jddt.v10i3-s.4060

*Address for Correspondence:

Mallya Suma V, Associate professor, Sri Dharmasthala Manjunatheshwara College of Ayurveda, Kuthpady, Udupi, Karnataka 574 118, India

\section{INTRODUCTION:}

Traditional knowledge on herbs, their potential therapeutic effect was well known among people, also documented in classical text books of Ayurveda. Few they used directly from plant, few parts advised to use after drying, other after special processing, the main aim to get target therapeutic effect through hidden metabolites of these natural products ${ }^{1}$. Dhanyaka(Coriandrum sativum Linn.) belonging to family Apiaceae is a common aromatic edible herb, the fruits of which are used as Ahara and Oushadha in many therapeutic conditions ${ }^{2}$. The whole plant, as well as the fruits are used in the preparation of many formulations having therapeutic efficacy in trishna, Krimiroga, Daha, Mutravikara etc ${ }^{3}$. The fruits are to be preserved for a period of 1year and to be used for medicine. Adamalla explains that keeping certain drugs for period of one year can be taken as purana dravya and it increases the potency of the drug. ${ }^{4}$

Biological activity shown by different herbal drug depend on its chemical constituents ${ }^{5}$. Essential oils extracts are the products from the secondary metabolism of plants that have applications in ethno-medicine, food flavouring, food preservation, cosmetics and pharmaceutical industries. ${ }^{6}$ Dhanyaka (Coriandrum sativum Linn.) has been known to have abundant essential oil which has antimicrobial properties ${ }^{7}$.

Hence with above all mentioned facts, a research plan has been designed to investigate chemical constituents of fresh and old sample of Dhanyaka (Coriandrum sativum Linn.) through Gas chromatography, and to evaluate the anti- 
microbial activity of Nava And Purana Dhanyaka (Coriandrum sativum Linn.) through In-Vitro method.

\section{MATERIALS AND METHOD:}

\section{Sample collection:}

Matured whole fruits of Dhanyaka(Coriandrum sativum Linn.) were collected from the Rona, Gadag district, authenticated and voucher specimen deposited at department of Pharmaceutical Chemistry and Pharmacognosy, SDM Centre for research in Ayurveda and Allied sciences, Udupi(V/No.18060103).The fresh fruits named as $\mathbf{S 1}$ with which essential oil extracted using clevengers apparatus ${ }^{8}$. Few fruits were kept in an air tight container and stored for one year, and at the end of a year named as sample $\left(\mathbf{S}_{2}\right)$, essential oil extracted and stored. Both samples were subjected for GC and in-vitro antimicrobial activity.

\section{Gas chromatography}

\section{Methodology:}

Volatile oil in the drug was estimated by distilling the $500 \mathrm{~g}$ of coarsely powdered fruits of Coriandrum sativum Linn. with a mixture of $800 \mathrm{ml}$ of water, taken in a round bottom flask and connected to the Clevenger's apparatus and distillation was carried out. Volume of the essential oil was measured and sent for the Gas Chromatography study9. Methylated test sample was introduced into a stream of helium. The results were tabulated as per the retention time.

\section{In-vitro antimicrobial study}

\section{Methodology:}

The In-vitro Antimicrobial study is performed using well diffusion method ${ }^{10}$. Agar media was inoculated with loop of desired microorganism (Table 2). Test was conducted for different concentrations of extract at 10, 25, 50 and $80 \mu l$ and kept for incubation. The presence of zone of inhibition was observed on petridish with respect to standard drug.

Table 1: Microorganism strains used

\begin{tabular}{|l|l|l|}
\hline Microorganism strain & Code & Standard used \\
\hline Staphylococcus aureus & MTCC 3160 & Ampicillin \\
\hline Streptococcus pyogens & MTCC-86 & Ampicillin \\
\hline Escherichia coli & MTCC-42 & Ampicillin \\
\hline Candida albicans & MTCC- 183 & Clotrimazole \\
\hline
\end{tabular}

\section{OBSERVATION AND RESULT}

\section{Gas chromatography}

The fruits of Nava Dhanyaka (Coriandrum sativum Linn.) $\mathrm{S}_{1}$ yielded about $0.7 \mathrm{ml}$ of yellow coloured essential oil with pleasant aroma. The GC-MS analysis of the fruits showed presence of totally 40 compounds in which 17 compounds were identified by comparing their Mass Spectra with MS library. The fruits of Purana Dhanyaka (Coriandrum sativum Linn.) $\mathrm{S}_{2}$ yielded about $0.5 \mathrm{ml}$ of colourless essential oil with pleasant aroma. The GC-MS analysis of the fruits showed presence of totally 18 compounds in which 6 compounds were identified by comparing their Mass Spectra with MS library. Comparative essential oil composition of Nava $\left(S_{1}\right)$ and Purana Dhanyaka $\left(\mathrm{S}_{2}\right)$ (Coriandrum sativum Linn.) are given in Table 1, Figure 1.

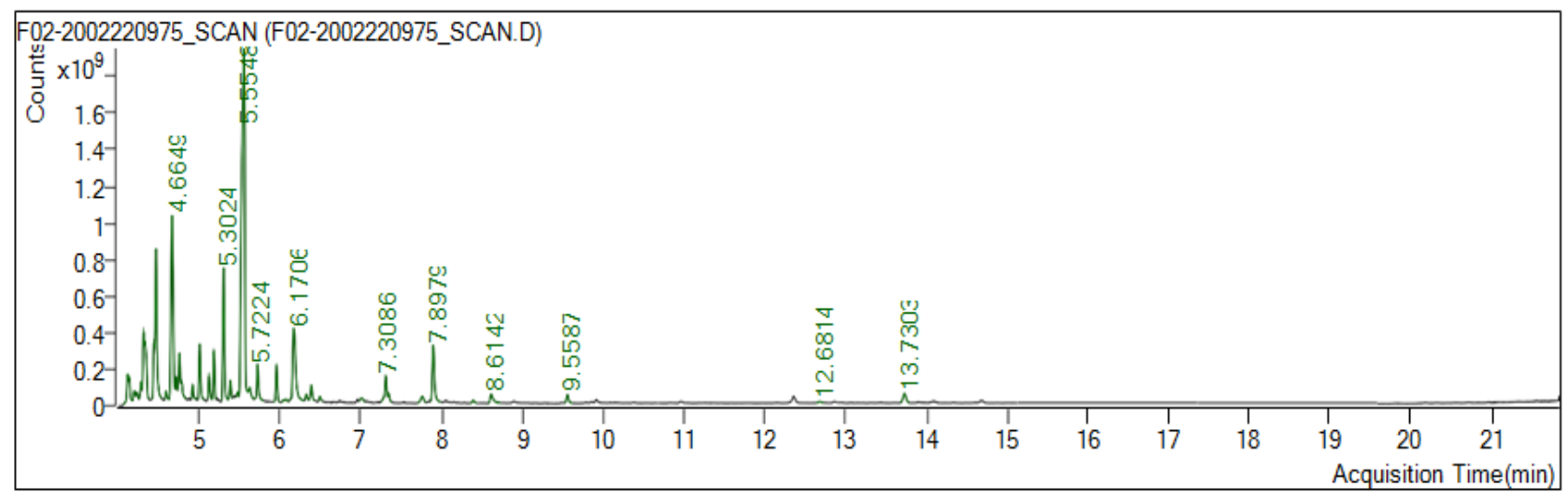

Figure 1: Gas chromatography of Essential oil Nava Dhanyaka(Coriandrum sativum Linn.) ( $\mathrm{S}_{1}$ )

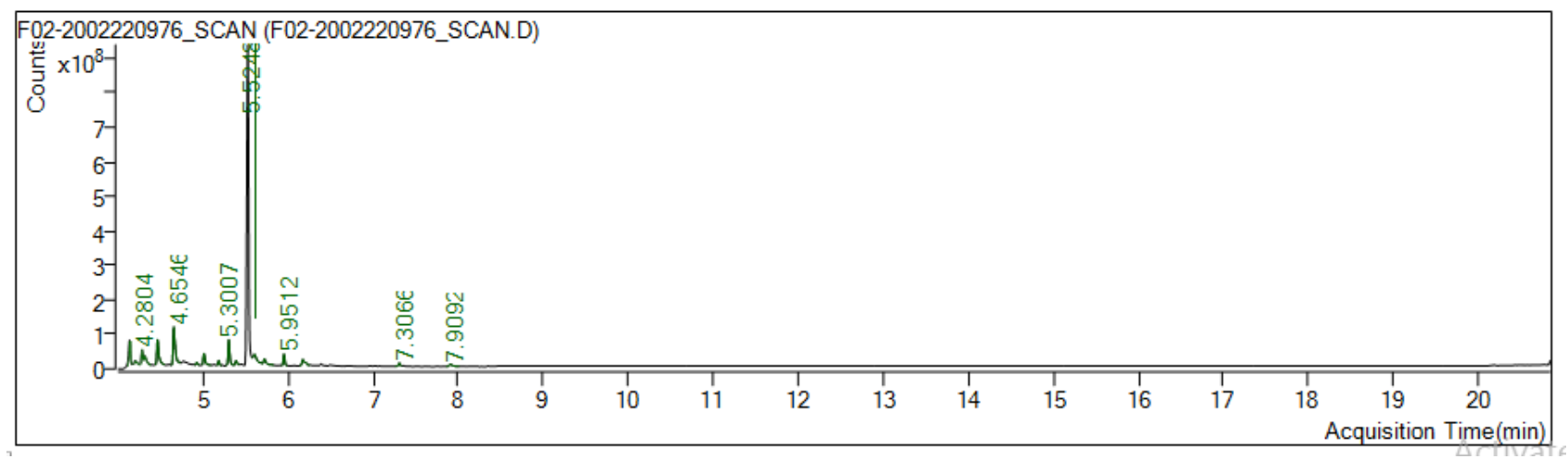

Figure 2: Gas chromatography of Essential oil of Purana Dhanyaka(Coriandrum sativum Linn.) (S 
Table 2: Essential oil composition of $\mathrm{Nava}\left(S_{1}\right)$ and Purana( $\left(\mathrm{S}_{2}\right)$ Dhanyaka(Coriandrum sativum Linn.)

\begin{tabular}{|c|c|c|}
\hline Phytochemical constituents & $\mathrm{S}_{1}$ & $\mathrm{~S}_{2}$ \\
\hline Bicyclo[2.2.1] heptan-2-ol, 1,7,7-trimethyl-, (1S-endo)- & - & + \\
\hline alpha.-Terpineol & + & - \\
\hline Decanal & + & - \\
\hline Bicyclo[3.1.1]hept-3-en-2-one, 4,6,6-trimethyl & + & - \\
\hline Geraniol & - & + \\
\hline Citronellol & + & + \\
\hline 2,6-Octadien-1-ol, 3,7-dimethyl-(Z) & + & - \\
\hline 1-Decanol & + & - \\
\hline Undecanal & + & - \\
\hline trans-Geranic acid methyl ester & + & - \\
\hline Myrtenyl acetate & + & - \\
\hline 6-Octen-1-ol, 3,7-dimethyl-, acetate & - & + \\
\hline 3,7-Dimethyloct-6-enyl ethyl carbonate & + & - \\
\hline 2,6-Octadien-1-ol, 3,7-dimethyl-, acetate, (Z)- & + & + \\
\hline Dodecanal & + & - \\
\hline Bicyclo[5.2.0]nonane,2-methylene-4,8,8-trimethyl-4-vinyl- & + & + \\
\hline (E)-Hexadec-2-enal & + & - \\
\hline Caryophyllene oxide & + & - \\
\hline 2-Hexadecenal(Z) & + & - \\
\hline 2-Pentadecanone, 6,10,14-trimethyl- & + & - \\
\hline
\end{tabular}

\section{In-vitro antimicrobial study}

Zone of inhibition of essential oil extract of Nava $\left(\mathrm{S}_{1}\right)$ and Purana $\left(\mathrm{S}_{2}\right)$ Dhanyaka (Coriandrum sativum Linn.) against Escherichia coli, Staphylococcus aureus, Streptococcus pyogenes and Candida albicansis displayed in Table 3,4,5 and 6 respectively.

Table 3: Zone of inhibition of Nava $\left(\mathrm{S}_{1}\right)$ and Purana $\left(\mathrm{S}_{2}\right)$ Dhanyaka (Coriandrum sativum Linn.) against Escherichia coli

\begin{tabular}{|c|c|c|c|}
\hline Sample & Volumes & S $_{1}$ - Zone of inhibition(Radius in mm) & S $_{2}$ - Zone of inhibition (Radius in mm) \\
\hline Essential oil extract & $10 \mu \mathrm{l}$ & 0 & 0 \\
\hline & $20 \mu \mathrm{l}$ & 0 & 0 \\
\hline & $50 \mu \mathrm{l}$ & 5 & 8 \\
\hline & $80 \mu \mathrm{l}$ & 6 & 0 \\
\hline Control (DW) & $50 \mu \mathrm{l}$ & 0 & 11 \\
\hline
\end{tabular}

Table 4: Zone of inhibition of Nava $\left(\mathrm{S}_{1}\right)$ and Purana $\left(\mathrm{S}_{2}\right)$ Dhanyaka (Coriandrum sativum Linn.) against Staphylococcus aureus

\begin{tabular}{|c|c|c|c|}
\hline Sample & Volume & S $_{1}$ - Zone of inhibition(Radius in $\mathrm{mm}$ ) & S $_{2}$ - Zone of inhibition(Radius in $\mathrm{mm}$ ) \\
\hline Essential oil extract & $10 \mu \mathrm{l}$ & 5 & 0 \\
\hline & $20 \mu \mathrm{l}$ & 6 & 0 \\
\hline & $50 \mu \mathrm{l}$ & 8 & 6 \\
\hline & $80 \mu \mathrm{l}$ & 9 & 0 \\
\hline Ctandard (Ampicillin) & $50 \mu \mathrm{l}$ & 0 & 8 \\
\hline
\end{tabular}


Table 5: Zone of inhibition of Nava $\left(\mathrm{S}_{1}\right)$ and Purana $\left(\mathrm{S}_{2}\right)$ Dhanyaka (Coriandrum sativum Linn.) against Streptococcus pyogenesis

\begin{tabular}{|c|c|c|c|}
\hline Sample & Volumes & $\begin{array}{c}S_{1} \text { - Zone of inhibition(Radius } \\
\text { in mm) }\end{array}$ & $\begin{array}{c}S_{2} \text { - Zone of inhibition(Radius } \\
\text { in mm) }\end{array}$ \\
\hline Essential oil extract & $10 \mu \mathrm{l}$ & 5 & 0 \\
\hline & $20 \mu \mathrm{l}$ & 6 & 0 \\
\hline & $50 \mu \mathrm{l}$ & 7 & 6 \\
\hline & $80 \mu \mathrm{l}$ & 8 & 0 \\
\hline Control (DW) & $50 \mu \mathrm{l}$ & 0 & 20 \\
\hline
\end{tabular}

Table 6: Zone of inhibition of Nava ( $\left.\mathrm{S}_{1}\right)$ and Purana $\left(\mathrm{S}_{2}\right)$ Dhanyaka (Coriandrum sativum Linn.) Against Candida albicans

\begin{tabular}{|c|c|c|c|}
\hline Sample & Volumes & $\begin{array}{c}S_{1} \text { - Zone of inhibition(Radius } \\
\text { in mm) }\end{array}$ & $\begin{array}{c}S_{2} \text { - Zone of inhibition(Radius } \\
\text { in mm) }\end{array}$ \\
\hline Essential oil extract & $10 \mu \mathrm{l}$ & 12 & 0 \\
\hline & $20 \mu \mathrm{l}$ & 13 & 11 \\
\hline & $50 \mu \mathrm{l}$ & 15 & 13 \\
\hline & $80 \mu \mathrm{l}$ & 15 & 0 \\
\hline Control (DW) & $50 \mu \mathrm{l}$ & 0 & 8 \\
\hline Standard (Clotrimazole) & $30 \mu \mathrm{g}$ & 10 & 13 \\
\hline
\end{tabular}

\section{DISCUSSION:}

Herbal drugs are seat of various active principle, proper collection time, preservation, processing decide its biological activity11. Dhanyaka (Coriandrum sativum Linn.) the dried fruits of which are used in medicine, which are said to be antimicrobial, appetizers, cooling. Fruits said to contain various phytochemical constituents with rich essential oil content. Classical texts of Ayurveda, advices them to use after a year. Gas chromatographic studies and anti-microbial study of Nava (fresh) and Purana (after 1 year) Dhanyaka (Coriandrum sativum Linn.) will help us to evaluate biological changes in a drug after preserving for a year.

The Essential oil of Nava Dhanyaka included 17 identified compounds which was dominated by monoterpenes like Terpineol, Verbenone, citronellol, acyclic monoterpenes like Methyl geranate, Myrtenyl acetate, sesquiterpene like Caryophyllene oxide. Terpineol is a common ingredient in perfumes, cosmetics and is abundantly used as a flavouring agent ${ }^{12} . \alpha$-terpineol has application in therapeutics due to its anti-oxidant, anti-ulcer and insecticidal properties. Verbenone, Methyl geranate, Myrtenyl acetategive a pleasant characteristic aroma. It also has anti-microbial properties ${ }^{13}$. Citronellol is also used as an anti-infective agent in many conditions ${ }^{14}$. The major aldehydes identified were Decanal, Undecanal, 1-Decanol and Dodecanal. Decanal is used in foods as a flavouring agent and also has anti-fungal property ${ }^{15}$.

The essential oil of Purana(old)Dhanyaka(C. Sativum) showed 6 identified compounds in which 3 constituents isoborneol, citronellyl acetate and geraniol were specifically identified in Purana Dhanyaka.
Isoborneol is extensively used as a food additive. It has camphor like aroma and is also used in insect repellants. It is used as a potential anti-viral agent and has anti-microbial, anti-tumour properties. Citronellyl acetate has potential larvicidal, bactericidal and fungicidal properties. Geraniol is one of the major constituent of Coriandrum sativum Linn. responsible for characteristic aroma. Along with being used as a flavouring agent, it is used as antibacterial, antifungal ${ }^{17}$.

In-vitro anti-microbial study of essential oil extract showed that Purana Dhanyaka $\left(\mathrm{S}_{2}\right)$ had better efficacy with respect to the standard against the strain Escherichia coli and Candida albicans. The essential oil extract of Nava Dhanyaka $\left(\mathrm{S}_{1}\right)$ had better efficacy with respect to the standard against only one bacterial strain ie., Streptococcus pyogens.

\section{CONCLUSION:}

Preserving certain crude drugs will make changes among biological activity by the influence of time, environmental factors, climatic changes etc and also brings about changes in the arrangement, structure and phyto-constituents of the crude drug. Dhanyaka(Coriandrum sativum Linn.) the fruits which advised to use in medicine after an year were evaluated for thier phyto-constituents and anti-bacterial activity after preserving for a period of an year and has shown significant results. This study gives us a better understanding of rationality behind the effect of collection and preservation of a crude drug and its impact on phytochemical constituents, pharmacotherapeutic actions. 


\section{REFERENCES:}

1. Thangavel A, Duraisamy S, Blakrishnan S; Phytochemical screening, Gas chromatography- Mass spectrometry(GCMS)analysis of phytochemical constituents and antibacterial activity of Coriandrum sativum(L.) SE; International journal of pharmacy and pharmaceutical sciences, 2015; 7(9):153-59.

2. Nadakarni KM., Indian Material Medica Vol-I, Dehradun; International book Distributor: 2006, p395

3. Anonymous. The wealth of India, A dictionary of Indian raw materials \& industrial products Vol 2, Newdelhi: Council of scientific \& industrial research: 2009 P.270- 275

4. Murthy Srikantha KR, Sarangadhara Samhita, Chaukambha Orientalia, 1997, Varanasi, p7-8

5. Sharma Rakesh K, Arora Rajesh; Herbal Drugs-A twenty first century perspective; New Delhi: Jaypee Brothers Medical Publishers, 2006p488-89

6. Evans WC., Trease and Evan's Pharmacognosy, $15^{\text {th }}$ ed. London: WB Saunders Ltd: 2002; p45- 150

7. Reneta nurzynska- Wierdak; Essentail oil composition of the coriander (Coriandrum sativum L.) herb depending on the development stage; Acta agrobotanica; 2013; 66(1):53-60.

8. Nicholes J. Sadgrove, Graham Lloyd Jones; A contemporary introduction to essential oil; Chemistry, bioactivity and prospects for Australian agriculture; Agriculture 2015; 5:48102.
9. Kanthal LK, Dey A, Bhojarju P; GC-MS analysis of bio-active compounds in methanolic extract of Lacctuca runcinate DC; Pharmacognosy Research; 2014; 6(1):58-61.

10. Mallya SV, Nesari T; Antibacterial activity profile and quality standards of Cymbopogon citratus Stapf- an aromatic grass used in Indian system of medicine; Journal of Ayurvedic and Herbal Medicine 2016; 2(3):63-66

11. Mukharjee PK, Quality Control of Herbal Drugs; New Delhi: Business Horizons; 2002; p68

12. Khaleel C, Tabanca N, Buchbauer G; Alpha Terpineol, a natural monoterpene; A review of its biological properties; open chemistry; 2018;16:349-361

13. Lindgren BS, Miller DR; Effect of Verbenone on fie species of Bark Beetles(Coleoptera; Scolytidae) in Lodgepole Pine Forests; Environmental Entomology, 2002 ; 31(5):759-65.

14. https://pubchem.ncbi.nim.nih.gov

15. https://en.m.wikepedia.org>wiki

16. Chen W, Viljoen AM; Geraniol- A review of a commercially important fragrance material; South African Journal of Botany; $2010 ; 76(4): 643-51$

17. Leite Maria Clerya Alvino, Bezerra André Parente de Brito, de Sousa Janiere Pereira, de Oliveira Lima Edeltrudes. Investigating the antifungal activity and mechanism(s) of geraniol against Candida albicans strains. Medical Mycology; 2015; 53(3):275-284. 